Article

\title{
Higher Education Students' Assessments towards Gamification and Sustainability: A Case Study
}

\author{
María Jesús Santos-Villalba ${ }^{1} \mathbb{1}$, Juan José Leiva Olivencia ${ }^{2} \oplus$, \\ Magdalena Ramos Navas-Parejo ${ }^{3}$ (D) and María Dolores Benítez-Márquez ${ }^{4, *(D)}$ \\ 1 Department of Didactics and Educational Organization, Faculty of Education, \\ Universidad Internacional de La Rioja, 26006 Logroño, Spain; mariajesus.santos@unir.net \\ 2 Department of Didactics and Educational Organization, Faculty of Education University of Malaga, \\ 29010 Malaga, Spain; juanleiva@uma.es \\ 3 Department of Didactics and Educational Organization, Faculty of Education, University of Granada, \\ 18010 Granada, Spain; magdalena@ugr.es \\ 4 Department of Applied Economics (Statistics and Econometrics), Faculty of Commerce and Management, \\ University of Malaga, 29010 Malaga, Spain \\ * Correspondence: bemarlo@uma.es
}

Received: 19 September 2020; Accepted: 10 October 2020; Published: 15 October 2020

check for updates

\begin{abstract}
Some academics are pushing for teaching staff to implement didactical practices to obtain sustainable behavior. Moreover, a fundamental element of gamification in all educational stages is the noteworthy effect it has on student motivation. In our study, we examined higher education students' assessments in the University of Malaga on the design of educational gamification and the teaching criteria that relate to gamification, and its effect on student's motivation, the applications of gamification, and the attitude towards sustainability. A questionnaire was administered to students studying for degrees in education from the University of Malaga. A total of 187 valid surveys were obtained. Partial least squares structural equation modeling was computed for these data based on an exploratory-confirmatory model and using SmartPLS version 3.3.2. A positive relationship between assessment of students' motivation and sustainability attitude was found. We found that the opinions of the students about the role of their training and teaching design material in education would affect students' motivation and the sustainability behavior, although the power of this last construct is moderate.
\end{abstract}

Keywords: gamification; motivation; attitude; sustainability attitude; PLS-SEM; higher education; mediation

\section{Introduction}

In recent years, there has been significant growth in the scientific literature on the implementation of non-traditional teaching methods in higher education to renew teacher training programs and improve teaching-learning processes [1-3]. Within a wide variety of constructive and innovative practical proposals, it is worth highlighting gamification as a pedagogical concept that is acquiring a wide epistemological and didactic development [4-6].

Following Deterding, Dixon, Khaled, and Nacke [7] gamification is defined as the use of game design elements in non-game related fields, and it means the implementation of this methodology in many areas that are different from where video games originated.

In the educational context, it is a procedure based on a system of scoring and recording rewards that provides students with tools for developing skills, solving problems related to social behavior, improving their performance, as well as greater involvement in the processes of teaching and 
learning [1,8-11]. However, Landers [12] suggests that serious games and gamification share a common set of tools, but the processes by which these elements affect learning differ.

The literature review reveals that this active methodology has been applied at all educational levels from primary education $[13,14]$, secondary education $[15,16]$, and higher education $[17,18]$. In this study, we focus on the university context in which gamification, as a technological innovation, is attractive to both teachers and students coming from the digital culture, opening new perspectives for future generations [11].

The effect on student motivation is one of the fundamental elements that characterizes the use of gamification in different educational stages. In this sense, other academics have analyzed how the design of activities that incorporate challenges typical of video games improves the level of commitment and motivation of students in formal learning contexts [19-21]. Another fundamental element of gamification is in the promotion of participation, so that learners are actively in control of their interactive learning, which is constantly being reviewed and changed [22-24]. A third element is the active promotion of conflict resolution linked to greater independence in the learning decisions that students can and should make about their trajectories and tendencies towards self-learning $[4,25]$.

Additionally, another positive effect of the use of this methodology is the creativity and innovation that is configured as an essential quality in the interdisciplinary and holistic approach of gamification. The active participation of students enhances the imagination and creative capacity for learning [26]. It implies an exercise of permanent questioning about how to approach teaching operatively with the clear orientation of achieving the best results in the conditions of greater well-being, participation, and inclusion of all students. In this sense, and as a basic axis of the gamified educational processes of high quality, it is worth highlighting the capacity of initiative, both personal and cooperative, that is generated in the students. The aim is to stimulate critical thinking and proactive behavior concerning student participation in university classrooms. Within this, the emotional factor derived from enjoyment, aesthetic enjoyment, and the satisfaction of curiosity as inherent ingredients of learning are transcendental. The increase in self-esteem, self-confidence, and the increase in the pedagogical commitment of teachers and students represents a clear opportunity to build more fruitful, dynamic, innovative, and democratic classes thanks to the creation of atmospheres and scenarios that optimistically invite learning [27]. This type of didactic methodology globally conceives educational processes, taking into account a wide number of ecological and inclusive teaching-learning contexts.

An example of this philosophy of learning that underlies gamification is found in Wang and Lieberoth's [28] study of the Kahoot application to more than 600 students. The results obtained highlight the exponential growth of learning using a platform that encourages dynamism and participation, offering significant improvements in increased student concentration, commitment, enjoyment, and motivation in line with other results [29-32].

Other studies have examined students' perceptions of the use of gamification in the teaching-learning context. In the study carried out by Gómez-Carrasco et al. [6], the results show that students have a positive opinion about the innovative potential of this methodology and its effect on motivation. Along the same lines, other studies $[2,21,33,34]$ show greater participation, autonomy, and commitment to learning.

Some limitations can also be found, and precautions should be taken when reviewing the literature. Clark et al. [35] point out that, although both studies and their data are indeed completely homogeneous environments, this scenario is almost impossible in practice, so they recommend not limiting future studies to the characteristics of higher-performing games. They also point out that one should move from trying to demonstrate whether games support learning to other types of studies that address cognitive outcomes and the value added that explores how design decisions driven by theory influence learning outcomes [35].

In the review carried out by Dichev and Dicheva [36], as a conclusion to their study [36], they suggest that gamification should be used in education as an element of motivation and that it should try to improve the student's commitment to the subject being studied. 
Finally, it should be noted that the use of gamification within a classroom not only contributes to an improvement in the students' academic training, but also to a substantial improvement in emotional and social terms [37]; therefore, it not only promotes more intuitive, direct, and dynamic cognitive constructions but also focuses on shaping the students' integral development, improving and facilitating communicative processes, autonomous learning, and teamwork, which reconcile very well with the need to learn, enjoy, and maintain a high expectation towards university learning.

\section{Gamification and Sustainability in the Higher Education}

Education for sustainable development concentrates its efforts on solving the planetary crisis that surrounds us, recognizing global problems such as the loss of biodiversity and climate change [38]. It relies on the involvement of various social institutions, including the university, as a place in which to acquire conceptual and procedural bases and values with which to exercise the profession from the perspective of ethics and care for the environment [39]. In this context, education is a key element and a priority to involve new generations to carry out personal actions that contribute towards respecting the environment and increasing social awareness [40-43].

In 2015, within the framework of the United Nations, world leaders unanimously adopted the document "Transforming our world: The Agenda 2030 for Sustainable Development", constituting the most ambitious global agreement in our recent history. This Agenda came into force on 1st January 2016, with the aim that by 2030, the world and all societies would be able to move towards a better, more sustainable, and inclusive future [44]. The Agenda defines the 17 Sustainable Development Goals, alluding to the need to promote education for sustainability, reorienting training plans at all levels of education, including university [45-47]. In the report derived from the previous document, the need to create learning spaces focused on students is highlighted, promoting a playful, innovative, and participatory pedagogy, capable of enhancing motivation and academic performance through attractive teaching methods such as gambling. In this way, it is possible to promote self-regulated learning based on an interdisciplinary approach to environmental conflicts. Given this panorama, the United Nations Educational, Scientific and Cultural Organization (UNESCO) and the United Nations (UN) are in favor of the use of video games in the educational space to provide training in topics related to social conflicts and environmental protection [48]. In the university context, in particular, there are more and more teachers committed to the use of gamification as an avant-garde methodology that favors learning through the implementation of virtual teaching experiences. According to Gatti, Ulrich, and Seele [49], the elements of game positively influence both the motivation and the experience of the student in terms of their pro-environmental attitudes, reaching higher levels of conceptual knowledge, awareness, and sensitivity towards ecological conflicts. In the same line, other authors suggest that serious environmental video games or game-playing platforms will improve the cognitive, emotional, and behavioral potential of students in problems related to climate change. When these factors converge with social interaction, the possibilities of implementing actions that will result in an improvement in environmental reality are increased [48,50,51].

Despite all the declarations of intent made by international organizations and the importance they give to the learning/teaching attitudes or patterns of behavior contributing to increased sustainability, there is a great deal of research that focuses on analyzing the process of curriculum greening at the university, which reveals the necessary involvement of teaching staff to generate changes in teaching following the sustainability paradigm [39,52-59] The implementation of education for sustainable development in education and higher education requires a commitment to reorienting learning experiences to make students aware of their environmental responsibilities, capabilities, and motivations [60].

Following Langendahl et al. [61], based on the gamification defined by Deterding et al. [7], gamification can be used as a means to engage students in management education for sustainability. Research in support of gamification, as an active and innovative methodology, for education for sustainable behavior is scarce $[49,61]$. The purpose of this study is, on the one hand, to identify the 
assessment of higher education university students about the convenience of the use of gamification as an active methodology in the teaching-learning process, as well as the implementation of education for sustainable development in higher education. On the other hand, to test these new ideas established by Gatti [49] and Langendahl [61]. Concretely, we analyze the effects of implementing the gamification on motivation, on different applications of the gamification, and on the development of attitude towards sustainable behavior - all refer to the perceptions of the university students interviewed-based on a model of structural equations. These students of education from university will be teachers in the future.

The literature described above allows us to consider a conceptual exploratory-confirmatory model. Several authors point out that the training and design of gamification affects motivation; the following hypotheses are confirmatory: $\mathrm{H} 1$ and $\mathrm{H} 2$ are established based on [28-32] and [48].

Hypothesis 1 (H1). Training and teaching criteria about gamification are directly positively related to motivation.

Hypothesis 2 (H2). Training and teaching criteria about gamification are directly and positively related to applications of gamification.

Following [49,61], H3 and H4 have been established.

Hypothesis 3 (H3). Training and teaching criteria about gamification are directly and positively related to attitude towards sustainability.

Hypothesis 4 (H4). Applications of gamification are directly related to attitude towards sustainability.

Now we test if there was a relation between the rest of the construct. The following hypothesis are descriptive-exploratory with no established sign:

Hypothesis 5 (H5). Global motivation directly affects applications of gamification.

Hypothesis 6 (H6). Global motivation directly affects attitude towards sustainability.

The final theoretical model includes four constructs with 12 items (from a total of 26 initial considered items): applications of gamification with two items; training and teaching criteria (in the design of gamification and the minimum criteria of the activities of subjects to learn) named with two items; global motivation with three indicators; attitude towards sustainability with two items.

\section{Data and Method}

\subsection{Data and Measures}

The data collection method used for this analysis was a questionnaire developed specifically for gamification and sustainability based on an established scale used in the studies by Aznar-Díaz, Raso-Sánchez, and Hinojo-Lucena [62] and the study by Domínguez Valerio, Moral Cuadra, Medina Viruel, and Orgaz-Agüera [63]. Most of the students had previous experience with gamification and sustainable behavior at university. The questionnaire includes items of gamification and sustainability. It was distributed online among the students at the University of Malaga's "virtual campus", based on the Moodle platform. Item descriptions are included in Table 1.

\subsection{Profile of Respondents}

This study involved a sample of 187 students of education at Malaga University. It was a voluntary questionnaire and anonymous. Data collection was performed by lectures between March and April of 
the year 2020. A total of 138 were female $(73.8 \%)$ and 49 males (26.2\%). The average age was 22.97 years old and age ranged between 18 and 43 years old. The profile of respondents is listed in Table 2.

Table 1. Initial items of the questionnaire.

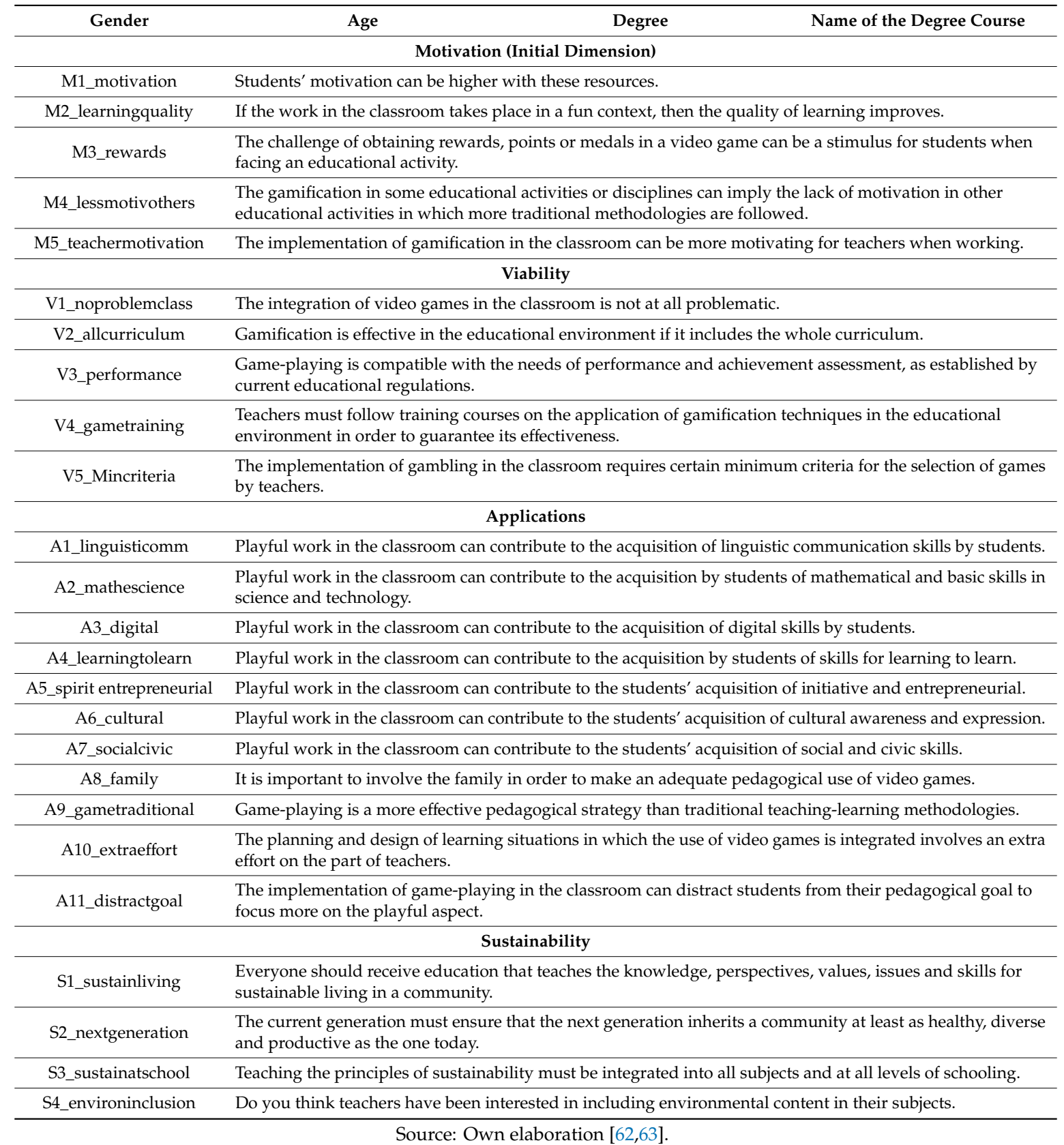

Table 2. Profile of interviewed students.

\begin{tabular}{cccccc}
\hline & Frequency & Percentage & Frequency & Percentage \\
\hline Age & & \multicolumn{5}{c}{ Gender } & \\
$18-20$ & 33 & 26.6 & Female & 138 & 73.8 \\
$21-24$ & 27 & 50.0 & Male & 49 & 26.2 \\
$25-30$ & 23 & 22.5 & Type of Higher Education & & \multirow{2}{*}{ Educational Studies } \\
$31-43$ & 11 & 5.9 & 187 & $100 \%$ \\
\hline
\end{tabular}

Source: SPSS v25. Note: $n=187$, missing 0 . 


\subsection{Scale of Items}

The Likert scale used is from 1 to 4 . Although the scale was previously established and validated [62,63], we ran a reliability test (coefficient of Cronbach's alpha) using statistical software SPSS v25 for the measurement scale on the construct and, further, in a stepwise process, some items were removed from each factor to increase the alpha coefficient. Assessment of the measurement scale's internal consistency revealed a coefficient alpha (CA) with a range of values from 0.64 to 0.91 for the respective items of each construct, which suggests an internal consistency for these scales (for the CA, see Table 3). We obtained a descriptive analysis of the questionnaire's items and then we applied a quantitative approach of a structural equation modeling based on variance estimated by partial least squares-structural equation modeling (PLS-SEM) to analyze the relationships between different dimensions of gamification in education and the future teachers' attitudes towards sustainability.

Table 3. Cronbach's alphas.

\begin{tabular}{cc}
\hline Constructs and Ítems & Cronbach's Alphas \\
\hline 1. Applications of gamification & 0.871 \\
A04_learningtolearn & \\
A05_entrepreneurial & \\
A06_cultural & \\
A07_socialcivic & 0.700 \\
S1_sustainliving & \\
S2_nextgeneration & \\
3. Global motivation & 0.641 \\
M1_motivation & \\
M3_rewards & \\
M5_teachermotivation & 0.704 \\
4. Training and teaching criteria & \\
V5_gametraining & \\
\end{tabular}

Considering that a 3 on the Likert scale represents an agreement, we focused on those items with a mean over this value. Based on the original dimensions of the survey's, the base of a gamification study [62]: the averages above 3 in the items of student motivation, quality teaching, obtaining rewards, and teacher motivation stand out in "global motivation"; in "viability of gamification" the relevant averages are those of training in gamification techniques and of the minimum criteria for selection of games by teachers; in "applications", the higher averages are presented in linguistics, mathematics, and science, digital competencies, learning to learn, cultural awareness, and expressions, social and civic competencies, as well as the role of the family in the appropriate pedagogical use of video games; finally, in "sustainability behaviors", the averages of greatest magnitude are those related to sustainability in living, at school, and next-generation (Table 4).

\subsection{Exploratory-Confirmatory Model and Reliability Test}

As was aforementioned, the theoretical model includes 4 constructs with 12 items. Concretely, the construct, which is related reflectively with the items: A04, the contributions to learning to learn; A05, the acquisition of initiative and entrepreneurial; A06, the acquisition cultural awareness and expression; A07, the acquisition of social and civic skills, represents the applications of the gamification and the latent variable was named so. The construct related with V4, teachers must follow training courses on the application of gamification techniques in the educational framework in order to guarantee its effectiveness; V5, the implementation of gamification in the classroom requires certain minimum criteria for the selection of games by teachers, is named training and teaching criteria. Items M1, student's motivation; M3, student's rewards; M5, teachers' motivation, represent the motivation either 
by the students or by the teacher and was called global motivation. Finally, there is a construct related with S1: everyone should receive education that teaches the knowledge, perspectives, values, issues and skills for sustainable living in a community, and S2: the current generation must ensure that the next generation inherits a community at least as healthy, diverse and productive as the one today, we understand this construct as the attitude towards sustainability.

Table 4. Descriptive statistics of the items on the original questionnaire.

\begin{tabular}{|c|c|c|c|c|c|c|c|c|c|}
\hline & No. & Miss. & Mean & Median & Min & $\operatorname{Max}$ & Standard Deviation & Excess Kurtosis & Skewness \\
\hline M1_motivation & 4 & 0 & 3.449 & 4 & 1 & 4 & 0.622 & 1.180 & -0.950 \\
\hline M2_learningquality & 5 & 0 & 3.727 & 4 & 1 & 4 & 0.562 & 7.690 & -2.515 \\
\hline M3_rewards & 6 & 0 & 3.449 & 4 & 1 & 4 & 0.630 & 1.109 & -0.970 \\
\hline M5_teachermotivation & 8 & 0 & 3.086 & 3 & 1 & 4 & 0.688 & -0.542 & -0.213 \\
\hline V1_noproblemclass & 14 & 0 & 2.182 & 2 & 1 & 4 & 0.827 & -0.561 & 0.221 \\
\hline V2_allcurriculum & 15 & 0 & 2.668 & 3 & 1 & 4 & 0.699 & -0.174 & -0.098 \\
\hline V4_gametraining & 17 & 0 & 3.449 & 4 & 1 & 4 & 0.604 & 0.386 & -0.756 \\
\hline V5_mincriteria & 18 & 0 & 3.583 & 4 & 1 & 4 & 0.554 & 1.300 & -1.092 \\
\hline A1_linguisticomm & 19 & 0 & 3.166 & 3 & 1 & 4 & 0.685 & 0.715 & -0.629 \\
\hline A2_mathescience & 20 & 0 & 3.487 & 4 & 1 & 4 & 0.579 & 1.727 & -0.947 \\
\hline A3_digital & 21 & 0 & 3.695 & 4 & 1 & 4 & 0.515 & 3.356 & -1.669 \\
\hline A4_learningtolearn & 22 & 0 & 3.278 & 3 & 1 & 4 & 0.564 & 0.517 & -0.231 \\
\hline A9_gametraditional & 27 & 0 & 2.706 & 3 & 1 & 4 & 0.868 & -0.593 & -0.231 \\
\hline A10_extraeffort & 28 & 0 & 2.872 & 3 & 1 & 4 & 0.874 & -0.567 & -0.376 \\
\hline A11_distractgoal & 29 & 0 & 2.326 & 2 & 1 & 4 & 0.875 & -0.685 & 0.133 \\
\hline S1_sustainliving & 30 & 0 & 3.701 & 4 & 1 & 4 & 0.492 & 3.244 & -1.556 \\
\hline S2_nextgeneration & 31 & 0 & 3.588 & 4 & 1 & 4 & 0.524 & 1.109 & -0.922 \\
\hline S3_sustainatschool & 32 & 0 & 3.620 & 4 & 1 & 4 & 0.547 & 1.814 & -1.279 \\
\hline S4_environinclusion & 33 & 0 & 2.209 & 2 & 1 & 4 & 0.756 & -0.234 & 0.230 \\
\hline
\end{tabular}

Note: Miss. = Number of missing values, computed with SmartPLS.

SEM is a statistical approach that allows us to evaluate a theoretical model and allows us to test all the relationships in a model at the same time among constructs and items, and among the latent variables. Data from a sample size of 187 completed questionnaires with no missing values are adequate for the PLS-SEM analysis method as it meets the minimum threshold of 100 samples established by earlier studies [64]. Furthermore, Chin [65] and Hair et al. [66] recommended that the minimum sample size should be 10 times the largest number of paths appointed to a particular construct. Later on, as shown in Figure 1, the maximum number of paths appointed to a latent variable was three in this study; a sample of 187 valid questionnaires was acceptable. PLS-SEM was performed on the collected data using SmartPLS 3.3.2 software [67].

The assessment of the PLS-SEM was carried out in two steps: Firstly, the outer model, and, secondly, the inner model. In the measurement (outer) model, each construct was related with their items reflectively (mode A); as a result, the evaluation of the measurement model included: Item reliability, Cronbach's alpha (CA), composite reliability (CR), average variance extracted (AVE), and discriminant validity. Concerning the structural model, an assessment of the structural model was conducted computing R2 and the coefficient Q2 by Stone-Geiser [68,69], and the constructs' collinearity. The significance of the path coefficients and the magnitude of the standardized beta-path coefficients were the second to last steps of the inner model's assessment [70] taking into account that the higher the magnitude of the path coefficient is, the stronger is the effect, in other words, the higher the path's relevance. The bootstrapping of 5000 re-samples of a sample size of 187 generated confidence intervals and assessed the significance of the path. The model is a mix of confirmatory-exploratory model, as a result, a two-tailed test was considered as only option that can be selected from the two available options: one or two tails. Lastly, mediation analysis was performed. 


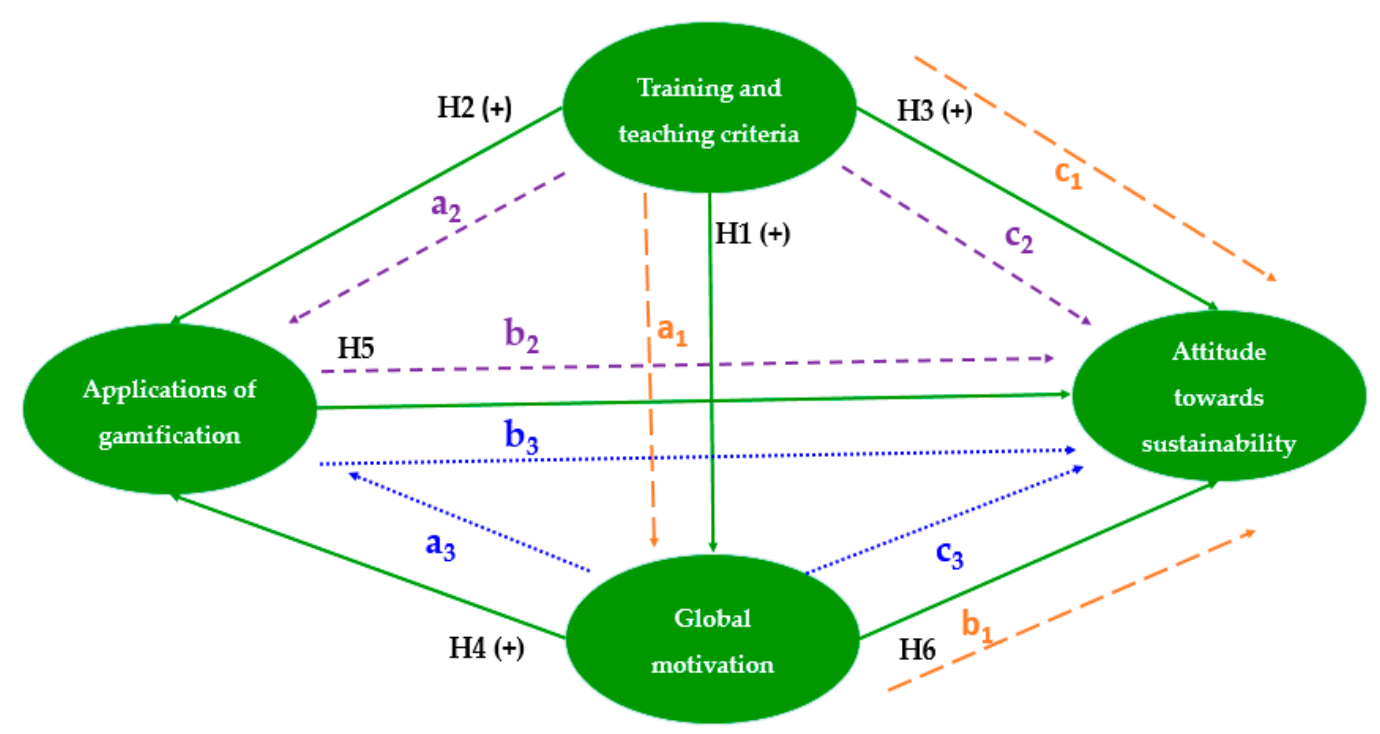

Figure 1. Theoretical exploratory-confirmatory model.

\section{Results of the PLS-SEM}

We followed a systematic process of examining the loadings following recommendations [71,72].

\subsection{Measurement Model}

The measurement model included constructs related to their respective items reflectively (mode A in SmartPLS); the evaluation of the measurement model includes: Item reliability, Cronbach's alpha (AC), composite reliability (CR), and average variance extracted (AVE) as it was mentioned in Section 3. Convergent validity and reliability are shown in Table 5 . Scale items loaded on their respective factors with loadings ranging from 0.73 to 0.91 ; the coefficient alpha ranged from 0.64 to 0.87 ; the average variance extracted ranged from 0.81 to 0.91 , confirming convergent validity; composite reliabilities ranged from 0.58 to 0.77 supporting reliability for all constructs.

Table 5. Item reliability, internal consistency reliability, and convergent validity.

\begin{tabular}{|c|c|c|c|c|c|c|c|}
\hline \multicolumn{8}{|c|}{ Outer Loadings } \\
\hline & 1 & 2 & 3 & 4 & $\mathrm{CA}>0.7$ & $\mathrm{CR}>0.7$ & AVE $>0.5$ \\
\hline 1. Applications of gamification & & & & & 0.871 & 0.906 & 0.708 \\
\hline A04_learningtolearn & 0.860 & & & & & & \\
\hline A05_entrepreneurial & 0.776 & & & & & & \\
\hline A06_cultural & 0.864 & & & & & & \\
\hline A07_socialcivic & 0.863 & & & & & & \\
\hline $\begin{array}{l}\text { 2. Attitude towards } \\
\text { sustainability }\end{array}$ & & & & & 0.700 & 0.869 & 0.768 \\
\hline S1_sustainliving & & 0.897 & & & & & \\
\hline S2_nextgeneration & & 0.856 & & & & & \\
\hline 3. Global motivation & & & & & 0.641 & 0.807 & 0.583 \\
\hline M1_motivation & & & 0.821 & & & & \\
\hline M3_rewards & & & 0.738 & & & & \\
\hline M5_teachermotivation & & & 0.729 & & & & \\
\hline 4. Training and teaching criteria & & & & & 0.704 & 0.870 & 0.769 \\
\hline V4_gametraining & & & & 0.846 & & & \\
\hline V5_mincriteria & & & & 0.908 & & & \\
\hline
\end{tabular}

Note: CA: Cronbach's alpha; CR: composite reliability; AVE: average variance extracted. 
Table 6 displays the results for the Fornell-Larcker procedure [73] to assess discriminant validity, which is satisfactory for all constructs, meaning that construct measures different concepts. The same conclusion was obtained with the results of the Heterotrait-Monotrait (HTMT) ratio criteria, as the values are below 0.85 [74].

Table 6. Discriminant validity: Fornell and Larcker, and Heterotrait-Monotrait ratio criteria.

\begin{tabular}{lcccc}
\hline \multicolumn{1}{c}{ Latent Variables } & $\mathbf{1}$ & $\mathbf{2}$ & $\mathbf{3}$ & $\mathbf{4}$ \\
\hline 1. Applications of gamification & 0.841 & 0.275 & 0.416 & 0.240 \\
2. Attitude towards sustainability & 0.241 & 0.877 & 0.483 & 0.645 \\
3. Global motivation & 0.342 & 0.332 & 0.764 & 0.589 \\
4. Training and teaching criteria & 0.231 & 0.459 & 0.402 & 0.877 \\
\hline
\end{tabular}

Note: The square of AVE in bold in the diagonal. Constructs' inter-correlations under diagonal and HTMT:

Heterotrait-Monotrait values over the diagonal.

\subsection{Structural Model}

The predictive power was measured by the coefficient of determination R2 and the Q2 of Stone-Geiser. Values of $0.67,0.33$, and 0.19 for R2 should be considered substantial, moderate, and weak, respectively [65]. The R2 values of each endogenous latent variable in this study were $0.128,0.157$ (all aforementioned lower than weak), and 0.234 (lower than moderate) for applications of gamification, global motivation, and attitude towards sustainability, respectively. The coefficient's Q2 were all greater than one. The measure named effect size (f2) is a complementary measure and it evaluates the increment in R2 by the omission of a construct.

We employed a variance inflation factor (VIF) to check the existence of harmful collinearity among predictors if any VIF is over 3.3 following the advice of Hair-Jr, Hult, Ringle, and Sarstedt [75]. In our study, the VIF obtained indicated that there is no problematic collinearity (Table 7). All the above-mentioned values are displayed in Table 7.

Table 7. R2, R2 adjusted, Q2, f2, and variance inflation factor (VIF).

\begin{tabular}{|c|c|c|c|c|c|c|c|c|c|}
\hline & \multirow[b]{2}{*}{ R2 } & & \multirow{2}{*}{ R2 Adjusted } & \multirow{2}{*}{ Q2 } & \multicolumn{3}{|c|}{$\mathrm{f} 2$} & \multicolumn{2}{|c|}{ VIF } \\
\hline & & & & & 1 & 2 & 3 & 1 & 3 \\
\hline 1. Applications of gamification & 0.128 & 0.118 & 0.059 & & 0.013 & & & 1.146 & \\
\hline 2. Attitude towards sustainability & 0.246 & 0.234 & 0.166 & & & & & & \\
\hline 3. Global motivation & 0.161 & 0.157 & 0.087 & 0.085 & 0.022 & & 1.192 & 1.294 & \\
\hline 4. Training and teaching criteria & & & & 0.012 & 0.156 & 0.192 & 1.192 & 1.207 & 1 \\
\hline
\end{tabular}

Figure 2 offers a comprehensive visualization of the path model for the estimated model. The results of our estimated path coefficient (direct effects) are included in Table 8.

Table 8. Direct effects and results of testing hypotheses.

\begin{tabular}{|c|c|c|c|c|c|c|}
\hline Hyp. & Paths & Coeff. & Sig. & T Stat. & P Val. & Supported/Rejected \\
\hline H1 & Training and teaching criteria $->$ Global motivation & 0.402 & $* * *$ & 4.430 & 0.000 & H1 supported \\
\hline $\mathrm{H} 2$ & Training and teaching criteria -> Applications of gamification & 0.112 & NS & 1.384 & 0.166 & $\mathrm{H} 2$ rejected \\
\hline H3 & Training and teaching criteria $->$ Attitude towards sustainability & 0.377 & NS & 4.607 & 0.000 & H3 supported \\
\hline $\mathrm{H} 4$ & Global motivation $->$ Applications of gamification & 0.297 & $* * *$ & 3.713 & 0.000 & H5 supported \\
\hline H5 & Applications of gamification $->$ Attitude towards sustainability & 0.104 & NS & 1.481 & 0.139 & $\mathrm{H} 4$ rejected \\
\hline H6 & Global motivation -> Attitude towards sustainability & 0.145 & NS & 1.758 & 0.079 & H6 rejected \\
\hline
\end{tabular}

Note. Hyp.: hypothesis; Coeff.: Coefficients; Sig.: significance; T Stat. t-Student statistics; P Val.: $p$-value; ${ }_{* * *} p<0.001$. Rejected at level of significance $=0.05$. 


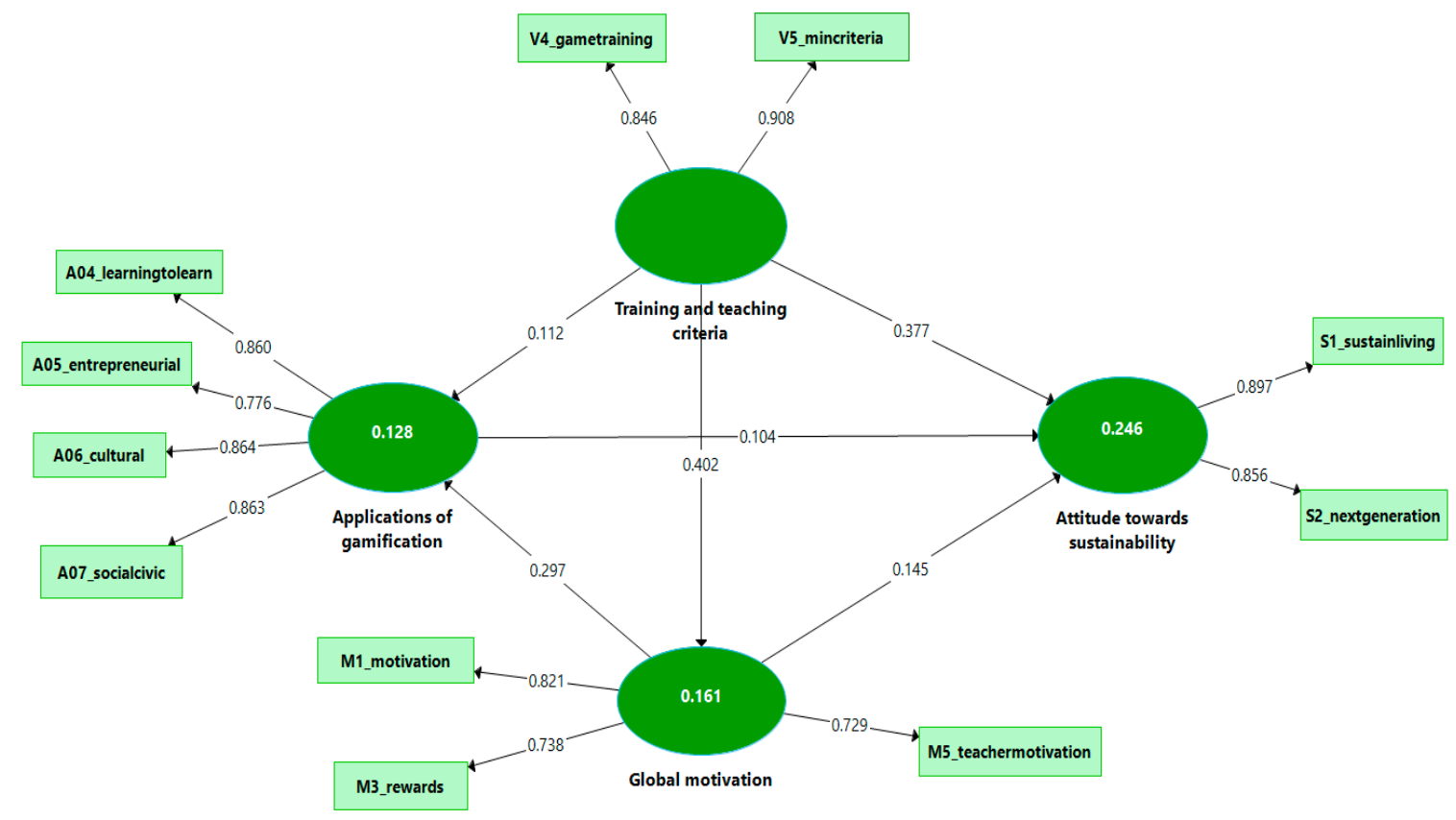

Figure 2. Estimated model (direct effects).

The hypotheses $\mathrm{H} 1, \mathrm{H} 3$, and $\mathrm{H} 4$ are supported. The results reveal the positive and significant direct effect of training and teaching criteria on the global motivation and attitude towards sustainability. Lastly, global motivation affects applications of gamification with sign-positive. Figure 3 summarizes the mediations under consideration.

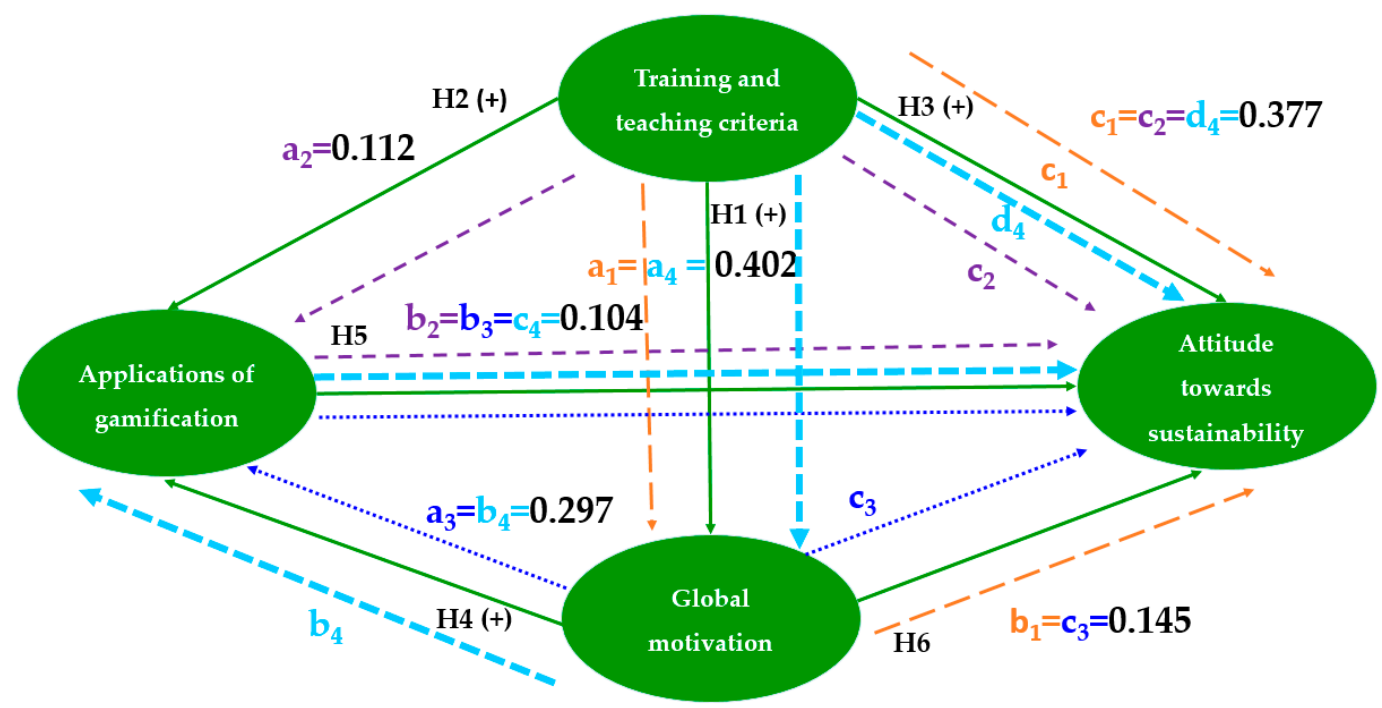

Figure 3. Global visualization of mediations.

\subsection{Mediation Analysis}

The mediating effect, indirect effect, or mediation involves a third variable intermediating the relationship between an exogenous variable and an endogenous variable, in this case, all variables are latent variables. That is, the effect of the independent construct on the dependent construct is mediated by the third construct named mediating latent variable or mediator [76].

Considering that the direct effects of the applications of gamification and global motivation are not significant to the attitude towards sustainability, as well as the training and teaching criteria to the applications of gamification. It is interesting to study the mediating role of said constructs. So, we went 
further and propose a more general hypothesis: instead of direct relations, we changed H1 to H6 to positive relations between each pair of constructs, and we added four relations of mediations, three sub-models with a two-path mediated effect, and one with three-path mediated effect. We have already tested the hypotheses: H1 to H6. Next, we test the mediation effects:

Hypothesis 7 (H7). Global motivation mediates between training and teaching criteria and attitude towards sustainability with a two-path mediated effect.

Hypothesis 8 (H8). Applications of gamification mediates the relationship between the training and teaching criteria, and the attitude towards sustainability with a two-path mediated effect.

Hypothesis 9 (H9). Global motivation mediates the relation between training and teaching criteria, and applications of gamification with a two-path mediated effect.

Hypothesis 10 (H10). The relationship between applications of gamification and attitude towards sustainability is sequentially mediated with a three-path mediated effect.

Figure 3 offers a comprehensive visualization including all the proposed mediations; Figure 4 separately displays the mediations. In PLS-SEM, the mediation was tested by the procedure developed by Nitzl et al. [76]. First, we obtained the significance of the indirect effects by random, with replacement bootstrap from the original data of 5000 subsamples computed by SmartPLS 3.3.2. Hayes and Scharkow [77] point out that the best approach for detecting a mediation effect is the bias-corrected bootstrap interval, although percentile intervals provide an adequate compromise concerning Type-I errors.

In the case of mediation reported in H8, global motivation does not mediate between training and teaching criteria and attitude towards sustainability, and neither does between application and attitude towards sustainability (H9). Concerning applications of gamification, it does not mediate between the training and teaching criteria and attitude towards sustainability, and neither does it between global motivation and attitude towards sustainability. In the case of the training and teaching criteria and applications of gamification (H7), global motivation mediates between them. It is worth noting that global motivation does not directly influence the applications of gamification. T-statistics and $p$-values of direct, indirect, and total effects are displayed in Table 9.

Finally, concerning the H10 mediation, the relationship was rejected between training and teacher criteria and attitude towards sustainability is sequentially and positively mediated by global motivation and applications of gamification. On the other hand, applications of gamification do not impact attitude towards sustainability (H5), and the rest of the hypotheses ( $\mathrm{H} 1, \mathrm{H} 2, \mathrm{H} 3, \mathrm{H} 4$, and $\mathrm{H} 6)$ are supported, not rejected, at a level of significance of $5 \%$.

Figure 5 shows the total effects.

Our results show the relevance of global motivation with a positive impact on applications of gamification, as well as on attitude towards sustainability. The role of training and teaching criteria positively affects applications of gamification, global motivation, and attitude towards sustainability. Our objective was reached, we conclude that our study contributes to the empirical analysis of the influence of gamification on motivation and sustainability. 


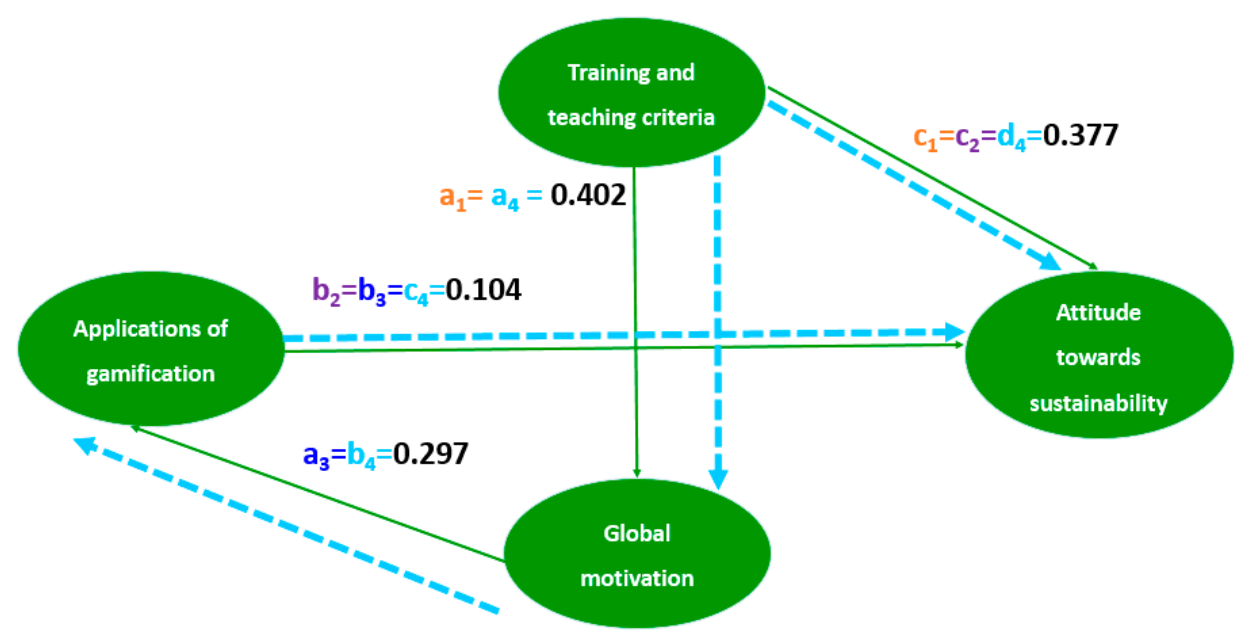

(a)

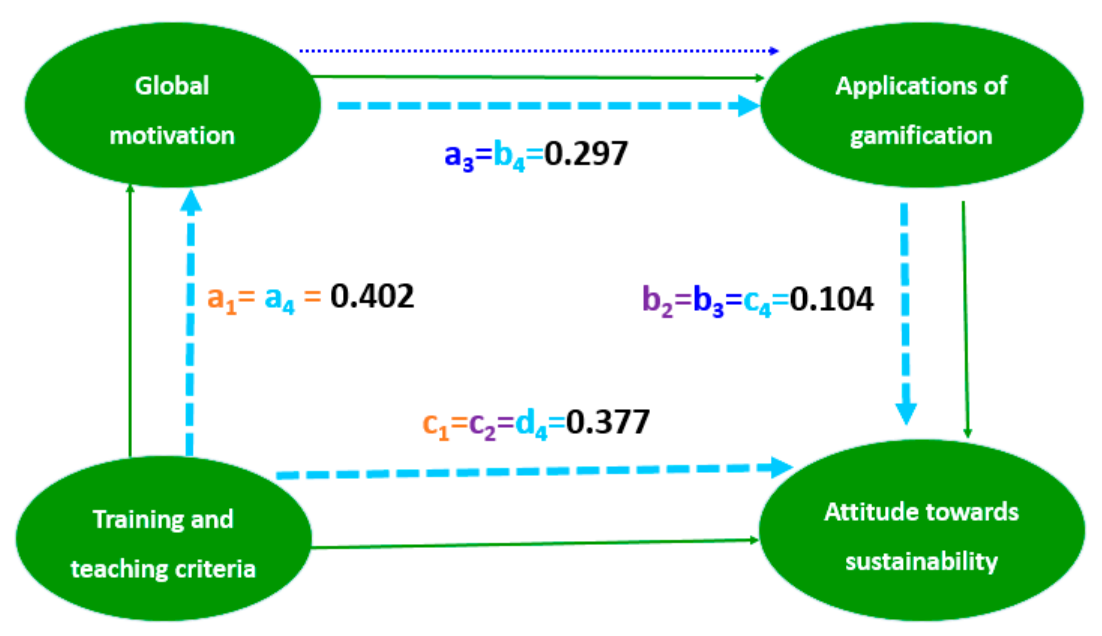

(b)

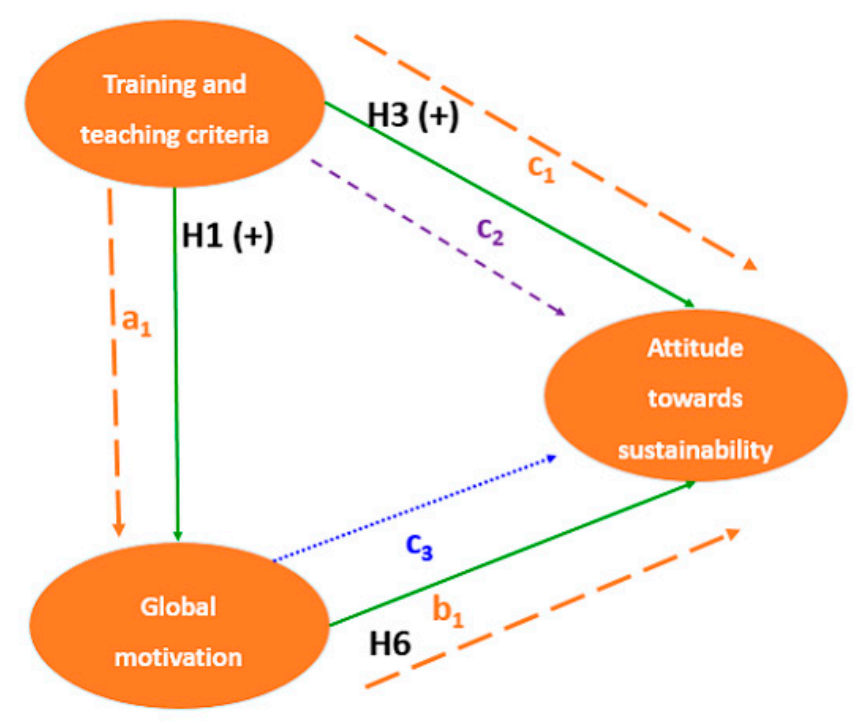

(c)

Figure 4. Cont. 


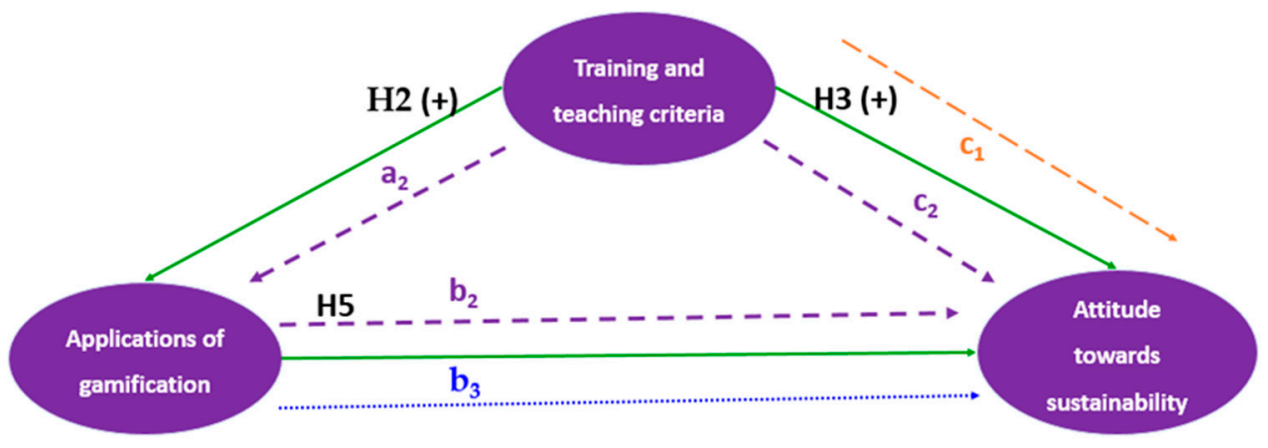

(d)

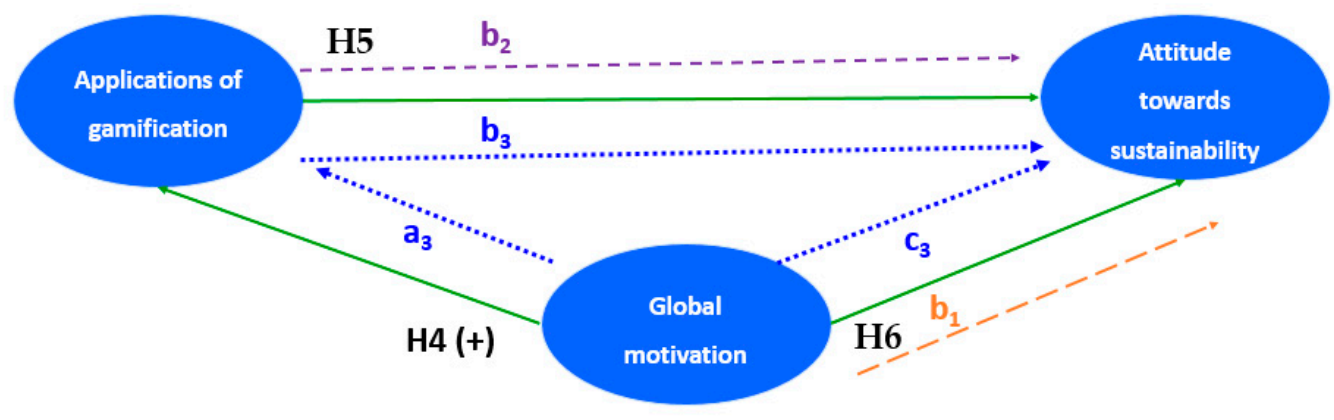

(e)

Figure 4. Individual visualization of sub-models of mediations. (a): Three-path mediation H10; (b): reorganization of mediation H10; (c): mediation H7; (d): mediation H8; (e): mediation H9.

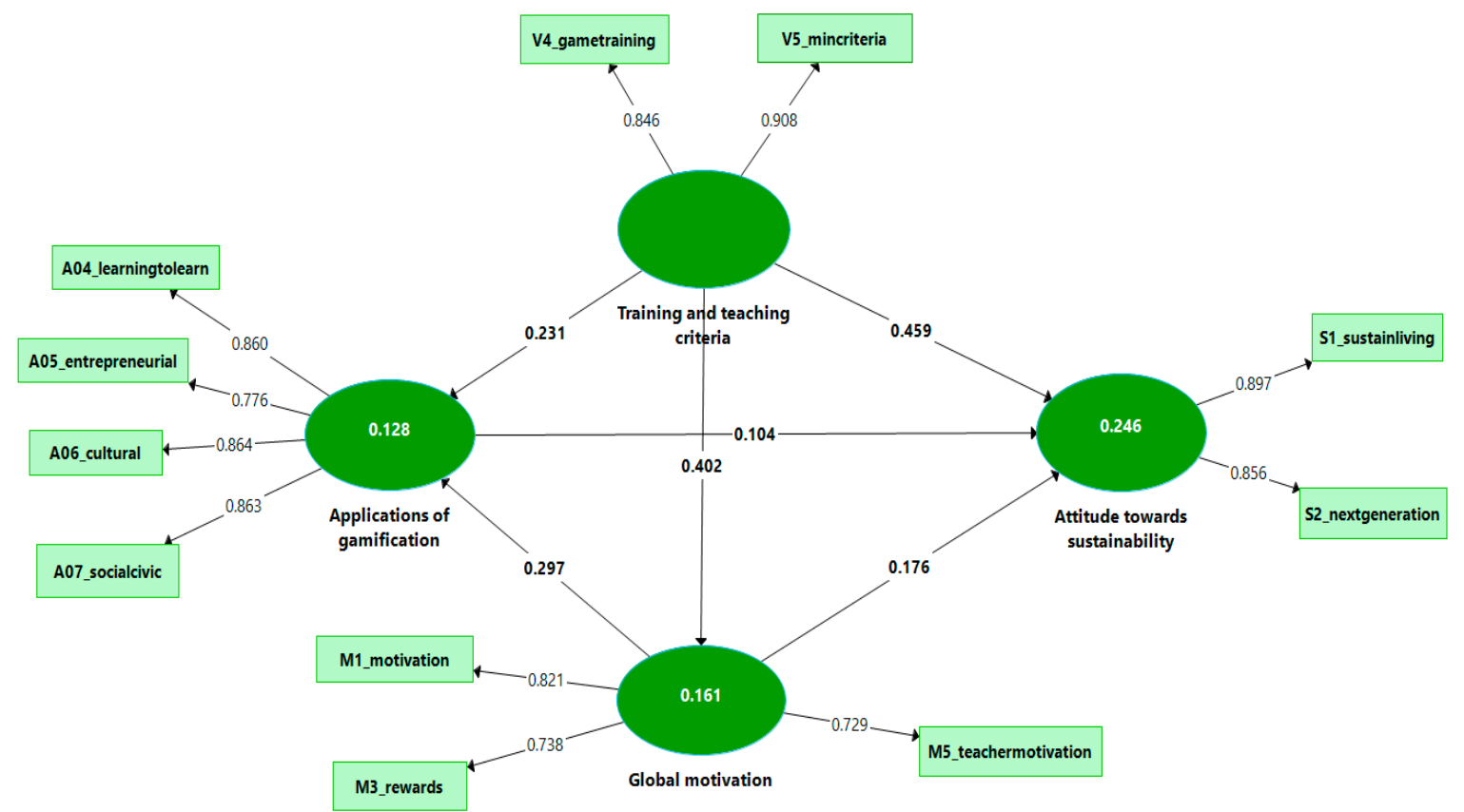

Figure 5. The estimated model showing the total effect in the inner model. 
Table 9. Direct, indirect, and total effect.

\begin{tabular}{|c|c|c|c|c|}
\hline Paths & $\begin{array}{l}\text { Letter in Figure } 3 \text { or } \\
\quad \text { Figure } 4 a-e\end{array}$ & VAF & Direct Effect & Sig. \\
\hline Training and teaching criteria $->$ Global motivation & $\mathrm{a} 1=\mathrm{a} 4$ & & 0.402 & $* * *$ \\
\hline Training and teaching criteria -> Applications of gamification & $\mathrm{a} 2$ & & 0.112 & NS \\
\hline Training and teaching criteria $->$ Attitude towards sustainability & $\mathrm{c} 1=\mathrm{c} 2=\mathrm{d} 4$ & & 0.377 & $* * *$ \\
\hline Applications of gamification -> Attitude towards sustainability & $\mathrm{b} 2=\mathrm{b} 3=\mathrm{c} 4$ & & 0.104 & NS \\
\hline Global motivation -> Applications of gamification & $\mathrm{a} 3=\mathrm{b} 4$ & & 0.297 & $* * *$ \\
\hline Global motivation -> Attitude towards sustainability & $\mathrm{b} 1=\mathrm{c} 3$ & & 0.145 & NS \\
\hline Path & & & Specif. Indirect & Sig. \\
\hline $\begin{array}{c}\text { Training and teaching criteria }->\text { Global motivation }-> \\
\text { Applications of gamification }\end{array}$ & $\mathrm{a} 4 \cdot \mathrm{b} 4$ & 51,701 & 0.119 & * \\
\hline $\begin{array}{c}\text { Global motivation }->\text { Applications of gamification }->\text { Attitude } \\
\text { towards sustainability }\end{array}$ & $\mathrm{b} 4 \cdot \mathrm{c} 4$ & 17,660 & 0.031 & NS \\
\hline $\begin{array}{l}\text { Training and teaching criteria }->\text { Global motivation }-> \\
\text { Applications of gamification }->\text { Attitude towards sustainability }\end{array}$ & $\mathrm{a} 4 \cdot \mathrm{b} 4 \cdot \mathrm{c} 4$ & 2716 & 0.012 & NS \\
\hline $\begin{array}{c}\text { Training and teaching criteria }->\text { Applications of gamification -> } \\
\text { Attitude towards sustainability }\end{array}$ & $\mathrm{a} 2 \cdot \mathrm{b} 2$ & 5044 & 0.012 & NS \\
\hline $\begin{array}{c}\text { Training and teaching criteria }->\text { Global motivation }->\text { Attitude } \\
\text { towards sustainability }\end{array}$ & $\mathrm{a} 1 \cdot \mathrm{b} 1$ & 12,663 & 0.058 & NS \\
\hline Path & & & Total Indirect & Sig. \\
\hline \multicolumn{5}{|l|}{$\begin{array}{c}\text { Applications of gamification -> Attitude towards sustainability } \\
\text { Global motivation -> Applications of gamification }\end{array}$} \\
\hline Global motivation -> Attitude towards sustainability & $\mathrm{b} 4 \cdot \mathrm{c} 4$ & & 0.031 & NS \\
\hline Training and teaching criteria -> Applications of gamification & $\mathrm{a} 4 \cdot \mathrm{b} 4$ & & 0.119 & * \\
\hline \multicolumn{5}{|l|}{ Training and teaching criteria $->$ Global motivation } \\
\hline Path & $\begin{array}{l}\text { Total }=\text { Direct }+ \\
\text { indirect }\end{array}$ & & Total & Sig. \\
\hline Applications of gamification -> Attitude towards sustainability & $\mathrm{b} 2=\mathrm{b} 3=\mathrm{c} 4$ (only direct) & & 0.104 & NS \\
\hline Global motivation $->$ Applications of gamification & $\mathrm{a} 3=\mathrm{b} 4$ (only direct) & & 0.297 & $* * *$ \\
\hline Global motivation -> Attitude towards sustainability & $\mathrm{b} 1+\mathrm{b} 4 \mathrm{c} 4=0.145+0.031$ & 0.176 & 0.176 & * \\
\hline Training and teaching criteria -> Applications of gamification & $\mathrm{a} 2+\mathrm{a} 4 \mathrm{~b} 4=0.112+0.119$ & 0.231 & 0.231 & * \\
\hline Training and teaching criteria $->$ Attitude towards sustainability & $\begin{array}{c}\mathrm{c} 1+\mathrm{a} 2 \cdot \mathrm{b} 2+\mathrm{a} 1 \cdot \mathrm{b} 1+ \\
\mathrm{a} 4 \cdot \mathrm{b} 4 \cdot \mathrm{c} 4\end{array}$ & 0.459 & 0.459 & $* * *$ \\
\hline Training and teaching criteria $->$ Global motivation & $\mathrm{a} 1=\mathrm{a} 4$ (only direct) & 0.402 & 0.402 & $* * *$ \\
\hline
\end{tabular}

Note. No sub-index used in letters to facilitate reading. Sig.: Significance based on two-side test. Specif. indirect: Specific indirect effects; T Stat.: T-Student statistics; P Val.: $p$-value; ${ }^{*} p<0.5 ;{ }^{* *} p<0.01 ;{ }^{* * *} p<0.001$.

\section{Discussion and Conclusions}

This study had several purposes, first, to analyze the perceptions that higher education students from Malaga University have about the use of gamification as an innovative methodology in the teaching-learning process. Related to this objective, the results reveal that these higher education students perceived gamification as an active methodology that has positive effects on the motivation of both students and teachers. In this sense, the participants show that obtaining rewards, points, or medals are tools that stimulate students in the development of an educational activity. These outcomes are consistent with other studies that have analyzed how the use of innovative techniques, including gamification, promotes and improves the motivation, perception, commitment, and social awareness of students in learning [19-21,29]. Concerning the viability of gambling in the teaching-learning context, this study highlights that the perceptions that the implementation of gamification in the classroom requires teachers to have adequate training in this methodology and its practical application to the classroom context. Moreover, following Aróstegui-Barandica and Darretxe-Urrutxi [30], teachers must organize, plan, and select the appropriate digital games for the teaching topic. The objective is to encourage curiosity towards learning new content; to adapt to the learning pace of the students; to motivate and generate a good climate in the classroom. Concerning the educational applications of gamification, the participants perceived that these applications in the classroom can contribute to the acquisition of skills, among which is learning to learn, digital skills, and social and civic values. These contributions are in line with other research [33,34], which indicates that gamification and the appropriate use of serious video games are key tools for teaching content, skills, abilities, and improving creative capacity. The study by Villalustre and Del Moral [32], carried out 
with students of the Degree in Pedagogy, obtained similar results, showing that the use of game dynamics applied in the realization of a project increased motivation, the level of satisfaction with the task entrusted, knowledge of theoretical contents, and the development of key generic competences.

Secondly, students' assessments of how education for sustainable development is carried out in the university context were studied. The results show that the respondents' attitudes are in favor of receiving an education based on the knowledge of values and skills for a life marked by sustainable nuances, as well as the power to ensure that the next generation has an environment as healthy as possible. These results are also in line with other studies that focus on giving students tools to respond to conflicts related to global degradation $[39,41,56,60]$. Similarly, participants have expressed that teachers are not actively involved in making the principles of education for sustainable development a reality. The green curriculum does not only include the incorporation of environmental contents in the teaching programs, but it is also necessary to integrate global changes in the teaching processes that link theory with practice, action with reflection and, in short, a global conception of education that can guarantee the development of the individual, as is pointed out by Aleixo et al. [40] and Murga-Menoyo and Novo [43].

Thirdly, following Dichev and Dicheva's recommendations [36], we have contributed to an empirical work that investigates. Concretely, we have estimated a PLS-SEM in which the effects of the training and teaching criteria of gamification in the educational context, students' and teachers' motivations, applications of gamifications, and attitudes towards sustainability are related.

The results of the PLS-SEM model are limited as they refer only to the higher education students from the University of Malaga towards gamification and education for sustainable behavior; therefore, the sample is not representative of the population of all students at this university. However, the results obtained are in line with the findings of other studies that have been carried out.

Specifically, the introduction of gamification in the educational framework is perceived as a positive influence on the motivation of students. $\mathrm{H} 1$ teacher training and planning in gamification directly and positively affects global motivation, student motivation and teacher motivation, and is supported in line with findings of several authors [19-21,29-32]. Furthermore, the global motivation mediates totally between training and teaching criteria, and applications of gamification.

Additionally, the motivation has a direct and positive influence on the acquisition of pro-environmental attitudes (H6), together with greater awareness and sensitivity towards environmental conflicts, which are included in the construct named attitude towards sustainability, being a descriptive result. The most relevant finding are the total effects of this exogenous construct-training and teaching criteria-on attitude towards sustainability $[49,61]$ and global motivation. Thus, as a result of these students' assessments, the key role of the teacher, as the main architect, is being responsible for motivating and encouraging students to develop sustainability skills, which come into play as he or she plans and designs educational activities with the environment as the central focus [48-51].

Among other conclusions, it can be pointed out that the use of active methodologies in higher education, such as gamification, requires that future education teachers assume a change of role to respond to the needs of today's society. To do so, they need to have acquired generic professional skills that are adjusted to the changes generated by the technological impact. Furthermore, their teaching methodology requires clear, rigorous planning and minimum criteria for the selection of teaching and learning materials to motivate both students and teachers; however, although the attitude towards gamification and pedagogical innovation is positive, maybe there are lecturers, who are reluctant to innovate methodology. This may be due to the demand for time and the imbalance it can create in terms of research when, up to now, research and academic papers are more relevant in the university's system of rewards compared with university teaching. It must be kept in mind that the various digital resources are continually becoming obsolete, which means that teaching staff must constantly update their knowledge. 
On the other hand, we must stress the existence of technological limits to reach the maximum levels of interactivity and participation in the development of gamification, either because all students do not have technological resources, or because the participation at a collaborative level among students (through groups) is not sufficiently developed. However, the continuous digital advances will progressively overcome some of these limitations. Similarly, it should be measured whether the increase in motivation and participation of students is transferred in parallel to an increase in the acquisition of knowledge and skills. It is also necessary to reconcile the different student profiles with the teaching style used by the teaching staff, making use of gamification.

Taking into account the contributions derived from this study concerning sustainability, we highlight that although there is a favorable predisposition on the part of teachers and students concerning a green curriculum, the reality shows that the training received in the university context related to the development of sustainability is scarce, and teachers do not have the necessary innovative tools with which to promote sustainability skills. For all these reasons, we need to use the active methodologies, such as gamification, that guarantee the motivation of students not only in terms of cognitive learning results but also in their attitudes towards sustainable development. However, this last result related to the education for sustainable behavior is merely descriptive-exploratory based on education students' assessment from one grade and one university and needs to be compared with future researchers' results. Future lines of research should continue to investigate the potential of teaching tools as a learning resource, of an education in values, and civic and environmental attitudes in the university context, above all, with more empirical studies and with control groups.

Author Contributions: Conceptualization, M.J.S.-V., J.J.L.O. and M.R.N.-P.; methodology, M.D.B.-M.; software, M.D.B.-M.; validation, M.D.B.-M.; formal analysis, M.D.B.-M.; investigation, M.J.S.-V., J.J.L.O., M.R.N.-P. and M.D.B.-M.; data curation, M.J.S.-V. and J.J.L.O.; writing-original draft preparation, M.J.S.-V. and M.D.B.-M.; writing—review and editing, M.D.B.-M.; visualization, M.J.S.-V. and J.J.L.O.; supervision, M.J.S.-V.; project administration, M.J.S.-V. All authors have read and agreed to the published version of the manuscript.

Funding: This research received no external funding.

Conflicts of Interest: The authors declare no conflict of interest.

\section{References}

1. Gómez-Carrasco, C.; Monteagudo-Fernández, J.; Moreno-Vera, J.; Sainz-Gómez, M. Effects of a gamification and flipped-classroom program for teachers in training on motivation and learning perception. Educ. Sci. 2019, 9, 299. [CrossRef]

2. González, G.; Skultety, L. Teacher learning in a combined professional development intervention. Teach. Teach. Educ. 2018, 71, 341-354. [CrossRef]

3. Hinojo-Lucena, F.J.; Aznar-Díaz, I.; Cáceres-Reche, M.P.; Romero-Rodríguez, J.M. Artificial intelligence in higher education: A bibliometric study on its impact in the scientific literature. Educ. Sci. 2019, 9, 51. [CrossRef]

4. Buckley, P.; Doyle, E. Gamification and student motivation. Interact. Learn. Environ. 2016, 24, 1162-1175. [CrossRef]

5. Kasurinen, J.; Knutas, A. Publication trends in gamification: A systematic mapping study. Comput. Sci. Rev. 2018, 27, 33-44. [CrossRef]

6. Whitton, N.; Langan, A.M. Fun and games in higher education: An analysis of UK student perspectives. Teach. High. Educ. 2018, 24, 1-14. [CrossRef]

7. Deterding, S.; Dixon, D.; Khaled, R.; Nacke, L. From game design elements to gamefulness: Defining "gamification". In Proceedings of the 15th International Academic MindTrek'11 Conference: Envisioning Future Media Environments, Tampere, Finland, 28-30 September 2011; pp. 9-15.

8. Batistello, P.; Pereira, A.T.C. El aprendizaje basado en competencias y metodologías activas: Aplicando la gamificación. Rev. Científica Arquit. Y Urban. 2019, 15, 31-42.

9. Ferriz-Valero, A.; Østerlie, O.; García Martínez, S.; García-Jaén, M. Gamification in physical education: Evaluation of impact on motivation and academic performance within higher education. Int. J. Environ. Res. Public Health 2020, 17, 4465. [CrossRef] 
10. García Fernández, J.; Fernández-Gavira, J.; Sánchez Oliver, A.J.; Grimaldi Puyana, M. Gamificación y aplicaciones móviles para emprender: Una propuesta educativa en la enseñanza superior. Int. J. Educ. Res. 2017, 8, 248-259.

11. Rojo, T.; González-Limón, M.; Rodríguez-Ramos, A. company-university collaboration in applying gamification to learning about insurance. Informatics 2019, 6, 42. [CrossRef]

12. Landers, R.N. Developing a theory of gamified learning: Linking serious games and gamification of learning. Simul. Gaming 2015, 45, 752-768. [CrossRef]

13. Marín-Díaz, V.; López-Pérez, M.; Maldonado-Berea, G.A. Can gamification be introduced within primary classes? Digit. Educ. Rev. 2015, 27, 55-68. [CrossRef]

14. Su, C.H.; Cheng, C.H. A Mobile gamification learning system for improving the learning motivation and achievements. J. Comput. Assist. Learn. 2015, 31, 268-286. [CrossRef]

15. Giannakos, M.N. Enjoy and learn with educational games: Examining factors affecting learning performance. Comput. Educ. 2013, 68, 429-439. [CrossRef]

16. Rico, M.M.; Agudo, J.E. Aprendizaje móvil de inglés mediante juegos de espías en Educación Secundaria. RIED Revista Iberoamericana de Educación a Distancia 2016, 19, 121-139. [CrossRef]

17. Urh, M.; Vukovic, G.; Jereb, E.; Pintar, R. The model for introduction of gamification into e-learning in higher education. Procedia Soc. Behav. Sci. 2015, 197, 388-397. [CrossRef]

18. Zamora-Polo, F.; Corrales-Serrano, M.; Sánchez-Martín, J.; Espejo-Antúnez, L. Nonscientific university students training in general science using an active-learning merged pedagogy: Gamification in a flipped classroom. Educ. Sci. 2019, 9, 297. [CrossRef]

19. Banfield, J.; Wilkerson, B. Increasing student intrinsic motivation and self-efficacy through gamification pedagogy. Contemp. Issues Educ. Res. 2014, 7, 291-298. [CrossRef]

20. Chapman, J.R.; Rich, P.J. Does educational gamification improve students' motivation? If so, which game elements work best? J. Educ. Bus. 2018, 93, 315-322. [CrossRef]

21. Mekler, E.D.; Brühlmann, F.; Tuch, A.N.; Opwis, K. Towards understanding the effects of individual gamification elements on intrinsic motivation and performance. Comput. Hum. Behav. 2017, 71, 525-534. [CrossRef]

22. Domínguez, A.; Saenz-De-Navarrete, J.; De-Marcos, L.; Fernández-Sanz, L.; Pagés, C.; Martínez-Herráiz, J.J. Gamifying learning experiences: Practical implications and outcomes. Comput. Educ. 2013, 63, 380-392. [CrossRef]

23. Hamari, J. Do badges increase user activity? A field experiment on the effects of gamification. Comput. Hum. Behav. 2017, 71, 469-478. [CrossRef]

24. Yildirim, I. The effects of gamification-based teaching practices on student achievement and students' attitudes toward lessons. Internet. High. Educ. 2017, 33, 86-92. [CrossRef]

25. Torres-Toukoumidis, Á.; Rodríguez, L.M.R.; Rodríguez, A.P. Ludificación y sus posibilidades en el entorno de blended learning: Revisión documental. RIED. Revista Iberoamericana de Educación a Distancia 2018, 21, 95-111. [CrossRef]

26. Plump, C.M.; LaRosa, J. Using Kahoot! in the classroom to create engagement and active learning: A game-based technology solution for elearning novices. Manag. Teach. Rev. 2017, 2, 151-158. [CrossRef]

27. Kirillov, A.V.; Vinichenko, M.V.; Melnichuk, A.V.; Melnichuk, Y.A.; Vinogradova, M.V. Improvement in the learning environment through gamification of the educational process. Int. Elect. J. Math. Ed. 2016, 11, 2071-2085.

28. Wang, A.I.; Lieberoth, A. The effect of points and audio on concentration, engagement, enjoyment, learning, motivation, and classroom dynamics using Kahoot! In Proceedings of the 10th European Conference of Game Based Learning-University of Western Scotland, Paisley, Scotland, UK, 5-14 October 2016; Thomas Connolly, L.B., Ed.; Academic Conferences and Publishing International Limited: Reading, UK, 2016; pp. 738-746.

29. Antonaci, A.; Klemke, R.; Specht, M. The Effects of Gamification in Online Learning Environments: A Systematic Literature Review. Informatics 2019, 6, 32. [CrossRef]

30. Aróstegui-Barandica, I.; Darretxe-Urrutxi, L. Estrategias metodológicas activas en la asignatura de "Bases de la Escuela Inclusiva" de la EU de Magisterio de Bilbao. Rev. Docencia Univ. 2016, 14, 315-340. [CrossRef]

31. Lin, D.T.A.; Ganapathy, M.; Kaur, M. Kahoot! It: Gamification in Higher Education. Pertanika J. Soc. Sci. Hum. 2018, 26, 565-582. 
32. Villalustre, L.; Del Moral, M.E. Gamificación: Estrategia para optimizar el proceso de aprendizaje y la adquisición de competencias en contextos universitarios. Digit. Educ. Rev. 2015, 27, 13-31.

33. Buzady, Z.; Almeida, F. FLIGBY-A serious game tool to enhance motivation and competencies in entrepreneurship. Informatics 2019, 6, 27. [CrossRef]

34. Campillo-Ferrer, J.M.; Miralles-Martínez, P.; Sánchez-Ibáñez, R.G. Gamification in higher education: Impact on student motivation and the acquisition of social and civic key competencies. Sustainability 2020, 12, 4822. [CrossRef]

35. Clark, D.B.; Tanner-Smith, E.E.; Killingsworth, S.S. Digital games, design, and learning: A systematic review and meta-analysis. Educ. Res. 2016, 86, 79-122. [CrossRef]

36. Dichev, C.; Dicheva, D. Gamifying education: What is known, what is believed and what remains uncertain: A critical review. Int. J. Educ. Technol. High. Educ. 2017, 14, 1-36. [CrossRef]

37. Rodríguez Jiménez, C.; Ramos Navas-Parejo, M.; Santos Villalba, M.J.; Fernández Campoy, J.M. El uso de la gamificación para el fomento de la educación inclusiva. Int. J. New Educ. 2019, 2, 40-59. [CrossRef]

38. Giangrande, N.; White, R.M.; East, M.J.R.; Clarke, T.; Saloff Coste, M.; Penha-Lopes, G. A competency framework to assess and activate education for sustainable development: Addressing the UN sustainable development goals 4.7 challenge. Sustainability 2019, 11, 2832. [CrossRef]

39. Álcala del Olmo Fernández, M.J. Análisis de la implementación de la sostenibilidad en el escenario universitario portugués: Principales barreras y desafíos curriculares. Rev. Espac. 2020,41,16. Available online: https://www.revistaespacios.com/a20v41n16/20411627.html (accessed on 30 June 2020).

40. Aleixo, A.M.; Azeiteiro, U.; Leal, S. UN decade of education for sustainable development: Perceptions of higher education institution's skateholders. In Handbook of Theory and Practice of Sustainable Development in Higher Education; Leal Filho, W., Azeiteiro, U., Alves, F., Molthan-Hill, P., Eds.; Springer: Berlin, Germany, 2017; pp. 417-429.

41. Cebrián, G.; Junyent, M.; Mulá, I. Competencies in education for sustainable development: Emerging teaching and research developments. Sustainability 2020, 12, 579. [CrossRef]

42. Napal, M.; Mendióroz-Lacambra, A.M.; Peñalva, A. sustainability teaching tools in the digital age. Sustainability 2020, 12, 3366. [CrossRef]

43. Murga-Menoyo, M.A.; Novo, M. Sostenibilidad, desarrollo "glocal” y ciudadanía planetaria. referentes de una pedagogía para el desarrollo sostenible. Teor. Educ. 2017, 29, 55-78. [CrossRef]

44. United Nations/SDGs. Transforming Our World: The 2030 Agenda for Sustainable Development Resolution Adopted by the General Assembly on 25 September 2015. Available online: https://www.un.org/ga/search/ view_doc.asp?symbol=A/RES/70/1\&Lang=E (accessed on 1 July 2020).

45. Gil Pérez, D.; Vilches, A. Educación para la sostenibilidad y educación en derechos humanos: Dos campos que deben vincularse. Teor. Educ. 2017, 29, 79-100. [CrossRef]

46. Murga-Menoyo, M.Á. La Formación de la Ciudadanía en el Marco de la Agenda 2030 y la Justicia Ambiental. Revista Internacional de Educación para la Justicia Social (RIEJS) 2018, 7, 37-52. [CrossRef]

47. UNESCO. Education for Sustainable Development Goals. Learning Objectives; United Nations Educational; Scientific and Cultural Organization: Paris, France, 2017.

48. Rojo, T.; Dudu, S. Los videojuegos en la implementación de políticas de mitigación del cambio climático. Ámbitos. Rev. Int. Comun. 2017, 37, 1-25. [CrossRef]

49. Gatti, L.; Ulrich, M.; Seele, P. Education for sustainable development through business simulation games: An exploratory study of sustainability gamification and its effects on students' learning outcomes. J. Clean. Prod. 2019, 207, 667-678. [CrossRef]

50. Katsaliaki, K.; Muysafee, N. Edutainement for sustainable development: A survey of games in the field. Simul. Gaming 2015, 46, 647-672. [CrossRef]

51. Ouariachi, T.; Li, C.Y.; Elving, W.J.L. Gamification approaches for education and engagement on pro-environmental behaviors: Searching for best practices. Sustainability 2020, 12, 4565. [CrossRef]

52. Albareda-Tiana, S.; Fernández Morilla, M.; Mallarach Carrera, J.M.; Vidal Raméntol, S. Barreras para la sostenibilidad integral en la universidad. Revista Iberoamericana de Educación 2017, 73, 253-272. [CrossRef]

53. Andrades Peña, F.J.; Larrán Jorge, M.; Muriel de Los Reyes, M.J. Analysing the incorporation of sustainability themes into the university curricula: A case study of a Spanish public university. Int. J. Sustain. Dev. World Ecol. 2018, 25, 642-654. [CrossRef] 
54. Dlouhá, J.; Glavič, P.; Barton, A. Higher education in Central European countries-Critical factors for sustainability transition. J. Clean. Prod. 2017, 151, 670-684. [CrossRef]

55. Jorgenson, S.N.; Stephens, J.C.; White, B. Environmental education in transition: A critical review of recent research on climate change and energy education. J. Environ. Educ. 2019, 50, 160-171. [CrossRef]

56. Leal Filho, W.; Wu, Y.C.J.; Brandli, L.L.; Avila, L.V.; Azeiteiro, U.M.; Caeiro, S.; Gama Madruga, L.R.d.R. Identifying and overcoming obstacles to the implementation of sustainable development at universities. J. Integr. Environ. Sci. 2017, 14, 93-108. [CrossRef]

57. Sánchez, F.; Segalás, J.; Vidal, E.; Martín, C.; Climent, J.; López, D.; Cabré, J.M. Improving engineering educators'sustainability competencies by using competency maps. J. Eng. Educ. 2018, 34, 1527-1537.

58. Serrate, S.; Martín, J.; Caballero, D.; Muñoz, J.M. Responsabilidad universitaria en la implementación de los objetivos de desarrollo sostenible. Eur. J. Child Develop. Educ. Psychopathol. 2019, 7, 83-196. [CrossRef]

59. Valderrama-Hernández, R.; Alcántara Rubio, L.; Sánchez-Carracedo, F.; Caballero, D.; Serrate, S.; Gil-Doménech, D.; Vidal-Raméntol, S.; Miñano, R. ¿Forma en sostenibilidad el sistema universitario español? Visión del alumnado de cuatro universidades. Educación XXI 2020, 23, 221-245. [CrossRef]

60. Mulà, I.; Tilbury, D.; Ryan, A.; Mader, M.; Dlouhá, J.; Mader, M.; Dlouha, J.; Mader, C.; Benayas, J.; Dlouhý, J.; et al. Catalysing change for sustainability in higher education: A review of professional development initiatives for university educators. Int. J. Sustain. High. Educ. 2017, 18, 798-820. [CrossRef]

61. Langendahl, P.A.; Cook, M.; Mark-Herbert, C. Exploring gamification in management education for Sustainable Development. Creat. Educ. 2017, 8, 2243-2257. [CrossRef]

62. Aznar-Díaz, I.; Raso-Sánchez, F.; Hinojo-Lucena, M.A. Percepciones de los futuros docentes respecto al potencial de la ludificación y la inclusión de los videojuegos en los procesos de enseñanza-aprendizaje. Educar 2017, 53, 11-28. [CrossRef]

63. Domínguez Valerio, C.M.; Moral Cuadra, S.; Medina Viruel, M.J.; Orgaz-Agüera, F. Actitud hacia el desarrollo sostenible en estudiantes de secundaria. Un caso de estudio. Rev. Espac. 2019, 40, 33. Available online: https://www.revistaespacios.com/a19v40n33/19403311.html (accessed on 30 June 2020).

64. Reinartz, W.; Haenlein, M.; Henseler, J. An empirical comparison of the efficacy of covariance-based and variance-based SEM. Int. J. Mark. Res. 2009, 26, 332-344. [CrossRef]

65. Chin, W.W. The Partial Least Squares approach to Structural Equation Modeling. In Modern Methods for Business Research; Marcoulides, G.A., Ed.; Lawrence Erlbaum Associates Publisher: Mahwah, NJ, USA; London, UK, 1998; pp. 295-336.

66. Hair, J.F.J.; Ringle, C.M.; Sarstedt, M. PLS-SEM: Indeed a silver bullet. J. Mark. Theory Pr. 2011, 19, $139-151$. [CrossRef]

67. Ringle, C.M.; Wende, S.; Becker, J.M. Software "SmartPLS 3" (version Professional 3.3.2, Update 2020). Boenningstedt. 2015. Available online: http://www.smartpls.com (accessed on 10 July 2020).

68. Stone, M. Cross-validatory choice and assessment of statistical predictions. J. R. Stat. Soc. Ser. B Stat. Methodol. 1974, 36, 111-147. [CrossRef]

69. Geisser, S. The predictive sample reuse method with applications. J. Am. Stat. Assoc. 1975, 70, 320-328. [CrossRef]

70. Chin, W.W. How to write and report PLS analyses. In Handbook of Partial Least Squares: Concepts, Methods and Applications (Springer Handbooks of Computational Statistics Series, Vol. II); Esposito Vinzi, V., Chin, W.W., Henseler, J., Wang, H., Eds.; Springer: Heidelberg, Germany; Dordrecht, The Netherlands; London, UK; New York, NY, USA, 2010; pp. 655-690.

71. Hair, J.F.; Hult, G.T.; Ringle, C.M.; Sarstedt, M.; Castillo-Apraiz, J.; Cepeda Carrion, G.; Roldán, J.L. Manual de Partial Least Squares Structural Equation Modeling (PLS-SEM); OmniaScience (Omnia Publisher SL): Barcelona, Spain, 2019.

72. Hair, J.F.; Risher, J.J.; Sarstedt, M.; Ringle, C.M. When to use and how to report the results of PLS-SEM. Eur. Bus. Rev. 2019, 31, 2-24. [CrossRef]

73. Fornell, C.; Larcker, D.F. Evaluating structural equation models with unobservable variables and measurement error. J. Mark. Res. 1981, 18, 39-50. [CrossRef]

74. Henseler, J.; Ringle, C.M.; Sarstedt, M. A new criterion for assessing discriminant validity in variance-based structural equation modeling. J. Acad. Mark. Sci. 2015, 43, 115-135. [CrossRef]

75. Hair, J.F., Jr.; Hult, G.T.M.; Ringle, C.M.; Sarstedt, M. A Primer on Partial Least Squares Equation Modeling (PLS-SEM); Sage Publication, Inc.: Thousand Oaks, CA, USA, 2013. 
76. Nitzl, C.; Roldán, J.L.; Cepeda-Carrion, G. Mediation analysis of partial least squares path modeling: Helping researchers discuss more sophisticated models. Ind. Manag. Data Syst. 2018, 116, 1849-1864. [CrossRef]

77. Hayes, A.F.; Scharkow, M. The relative trustworthiness of inferential test of the indirect effect in statistical mediation analysis: Does method really matter? Psychol. Sci. 2013, 24, 1918-1927. [CrossRef]

Publisher's Note: MDPI stays neutral with regard to jurisdictional claims in published maps and institutional affiliations.

(C) 2020 by the authors. Licensee MDPI, Basel, Switzerland. This article is an open access article distributed under the terms and conditions of the Creative Commons Attribution (CC BY) license (http://creativecommons.org/licenses/by/4.0/). 